\title{
Anna Hołownia
}

ORCID: 0000-0001-6949-1520

Specjalny Ośrodek Szkolno-Wychowawczy w Stoku Lackim

\section{PRACA SPECJALNEGO OŚRODKA SZKOLNO-WYCHOWAWCZEGO W CZASIE PANDEMII}

The activity of a special educational center during a pandemic

https://doi.org/10.34739/sn.2020.20.11

Wszyscy pedagodzy Specjalnego Ośrodka Szkolno-Wychowawczego (SOSW) w Stoku Lackim wykazali ogromne zaangażowanie w organizację nauczania na odległość. Przygotowali wiele materiałów na stronę internetową - skierowanych do rodziców i dzieci. W tak trudnej sytuacji starali się organizować zaplanowane w kalendarzu Ośrodka uroczystości. Światowy Dzień Wiedzy na temat Autyzmu, corocznie odbywający się w kinie Helios, został odwołany, ale konkurs plastyczny pt. „Moja niebieska podróż" odbył się przez Internet, podobnie jak pozostałe konkursy logopedyczne i czytelnicze: konkurs „Jedyna taka książka”, wspaniała akcja „Polska - moja Ojczyzna” oraz prezentacja na Dzień Dziecka.

Podczas pracy zdalnej wychowawcy klas i inni nauczyciele korzystali z technologii informatycznych: poczty e-mail, komunikatorów, strony WWW placówki, a także z telefonów i poczty tradycyjnej. Wychowawcy korzystali dodatkowo z wirtualnej tablicy Padlet, której zadaniem jest gromadzenie w jednym miejscu różnego rodzaju materiałów cyfrowych w ramach tematu określonego przez prowadzącego. Uczniom przeżywającym kryzys, borykającym się z problemami wynikającymi z obecnej sytuacji, np. z izolacją od rówieśników, z niemożliwością bezpośredniego komunikowania się, SOSW zaoferował pomoc psychologa i pedagoga. 
Dnia 18 maja Ośrodek wznowił zajęcia rewalidacyjne dla dzieci, których rodzice wyrazili na to zgodę. Bardzo ważne było przywrócenie przerwanych wcześniej zajęć terapeutycznych dla dzieci o specjalnych potrzebach edukacyjnych. Specjalny Ośrodek Szkolno-Wychowawczy w Stoku Lackim jest placówką dla uczniów niepełnosprawnych intelektualnie w stopniu umiarkowanym, znacznym i głębokim, którzy mają obniżoną odporność immunologiczną, cierpią na rzadkie choroby genetyczne, wady serca itp.

Dnia 25 maja swoją działalność edukacyjną w zakresie wychowania przedszkolnego wznowiło Powiatowe Przedszkole Specjalne. Opracowano procedury dotyczące funkcjonowania Przedszkola oraz całościowej organizacji pracy w Ośrodku w warunkach obostrzeń sanitarnych nałożonych przez Głównego Inspektora Sanitarnego.

\section{Problemy szkoły w czasie kształcenia zdalnego:}

- wykluczenie cyfrowe uczniów i nauczycieli;

- brak dostępu do urządzeń i nieumiejętność obsługiwania oprogramowania przez uczniów;

- brak dostępu do sieci (zarówno uczniów, jak i nauczycieli), problemy z przepustowością Internetu;

- brak technicznych możliwości przyłączenia Internetu w niektórych domach;

- zbyt mała liczba komputerów w rodzinach wielodzietnych;

- brak możliwości samodzielnego uczenia się w przypadku uczniów z niepełnosprawnością intelektualną umiarkowaną i znaczną;

- duże obciążenie psychiczne rodziców dzieci ze specjalnymi potrzebami edukacyjnymi (dużo dodatkowych obowiązków);

- brak terapii dla dzieci z dysfunkcjami (m.in. ruchowymi), brak rehabilitacji, integracji sensorycznej, terapii taktylnej;

- brak kontaktów i relacji rówieśniczych pomiędzy wychowankami;

- obciążenie psychiczne i przemęczenie nauczycieli;

- brak szkoleń i wsparcia metodycznego dla nauczycieli; 
- stres przeżywany przez uczniów i rodziców w związku z nową, trudną sytuacją;

- lęk, niezrozumienie zagrożenia, jakim jest koronawirus.

\section{Problemy rodziców:}

- dużo kart pracy, a mało zadań praktycznych;

- pogorszenie stanu zdrowia dziecka wywołane brakiem terapii;

- ciągła opieka nad dzieckiem;

- konieczność organizowania dzieciom czasu wolnego;

- przejęcie obowiązku edukowania dzieci;

- współdzielenie jednego komputera przez rodzeństwo - jako problem organizacyjny dla rodziców.

\section{Specjalny Ośrodek Szkolno-Wychowawczy w Stoku Lackim}

SOSW mieści się w zabytkowym, neorenesansowym pałacu wybudowanym w 1875 r. dla Józefa Joachima Wyszomirskiego według projektu architekta Bolesława Podczaszyńskiego. Ośrodek powstał 1 września 1985 r. i prowadzony jest przez Starostwo Powiatowe w Siedlcach. Budynek główny otacza park o powierzchni 4,3 ha wpisany do rejestru zabytków i będący pod stałą opieką wojewódzkiego konserwatora zabytków. Budynek i znajdujące się w nim pomieszczenia dostosowane są do potrzeb osób niepełnosprawnych.

Specjalny Ośrodek Szkolno-Wychowawczy w Stoku Lackim jest placówką przeznaczoną dla dzieci i młodzieży niepełnosprawnych intelektualnie w stopniu umiarkowanym, znacznym i głębokim. Placówka posiada bogate doświadczenie zarówno jeśli chodzi o wychowanie i opiekę, jak i kształcenie uczniów ze specjalnymi potrzebami edukacyjnymi. Jej pracownicy stwarzają odpowiednie warunki do wszechstronnego rozwoju uczniów. Atutem naszej szkoły jest wykwalifikowana kadra doświadczonych nauczycieli. Ośrodek zapewnia opiekę pedagogów, logopedów, psychologa i pielęgniarki. Prowadzimy zajęcia edukacyjne i rewalidacyjne, m.in. z komunikacji alternatywnej i wspomagającej, a także w ramach terapii taktylnej, ćwiczeń z integracji sensorycznej, rehabilitacji ruchowej, terapii polisensorycznej, terapii metodą EEG Bio- 
feedbacku; a jeśli chodzi o oddziaływania rewalidacyjne - odbywają się zajęcia korekcyjno-kompensacyjne, zajęcia w ramach terapii metodą A. Tomatisa, zajęcia rozwijające umiejętności społeczne uczniów z autyzmem oraz zajęcia z pomocy psychologiczno-pedagogicznej.

Strukturę ośrodka przedstawiono poniżej.

Powiatowe Przedszkole Specjalne w Stoku Lackim powstało z myślą o dzieciach niepełnosprawnych intelektualnie w stopniu umiarkowanym i znacznym, dzieciach z autyzmem oraz dzieciach z niepełnosprawnościami sprzężonymi. Grupy przedszkolne pracują w małych zespołach - dla dzieci z autyzmem i niepełnosprawnościami sprzężonymi powstają zespoły 2-4-osobowe. Dla dzieci z umiarkowaną i znaczną niepełnosprawnością intelektualną - 8-osobowe. Zajęcia odbywają się w dwóch specjalnie przygotowanych salach przedszkolnych. Sale wyposażona się w specjalistyczne urządzenia dostosowane do specyficznych potrzeb dzieci. Praca dydaktyczno-terapeutyczna i opiekuńcza prowadzona jest zgodnie z podstawą programową wychowania przedszkolnego, programem wychowania przedszkolnego oraz z indywidualnymi programami edukacyjno-terapeutycznymi (IPET). W zależności od potrzeb przedszkolaków edukacja wspomagana jest metodami zaczerpniętymi z: terapii pedagogicznej, terapii psychologicznej, terapii sensorycznej, terapii taktylnej. Stosowane są także metody komunikacji alternatywnej i wspomagającej (AAC), rehabilitacja ruchowa, stymulacja polisensoryczna w Sali DoświadCzania Świata, dogoterapia, hipoterapia. Dzieci mają zapewnioną edukację przedszkolną w wymiarze 5 godzin dziennie, później są zajęcia rewalidacyjne.

Publiczna Szkoła Podstawowa Specjalna przeznaczona jest dla uczniów z niepełnosprawnością intelektualną, uczniów z niepełnosprawnościami sprzężonymi, w tym z autyzmem, niedosłuchem, niedowidzeniem i niepełnosprawnością ruchową. Nauczanie i wychowanie ma za zadanie osiągnięcie możliwie wszechstronnego rozwoju uczniów, ich rewalidację i uspołecznienie w optymalnym, dostępnym dla nich zakresie. Zespół klasowy liczy od czterech do ośmiu uczniów. Treści programowe są w pełni dostosowane do możliwości uczniów. Edukacja opiera się na 
diagnozie pedagogicznej, planowaniu i realizacji indywidualnych programów edukacyjno-terapeutycznych (IPET).

Szkoła Specjalna Przysposabiająca do Pracy przeznaczona jest dla absolwentów szkół specjalnych, zarówno gimnazjów, jak i szkół podstawowych. Cykl nauczania w szkole trwa 3 lata. Głównym celem kształcenia jest przygotowanie uczniów do dorosłości i podjęcia aktywności zawodowej w warunkach pracy chronionej, w warsztatach terapeutycznych lub we własnym gospodarstwie domowym. Wzbogaceniem oferty edukacyjnej są praktyki wewnętrzne i zewnętrzne, m.in. w Zakładzie Aktywizacji Zawodowej w Siedlcach.

Internat pełni w Ośrodku funkcję opiekuńczo-wychowawczą i rewalidacyjną. W okresie nauki szkolnej zapewnia wychowankom prawidłowe warunki do rozwoju psychofizycznego. Grupy wychowawcze są jednostkami internatu, w których realizowana jest praca dydaktyczno-wychowawczo-opiekuńcza i rewalidacyjna. Liczba wychowanków w grupie wychowawczej odpowiada liczbie uczniów w zespole klasowym. Grupą opiekuje się dwóch wychowawców, którzy posiadają odpowiednie kwalifikacje do pracy z dziećmi z niepełnosprawnością intelektualną. Głównym zadaniem internatu jest wszechstronny rozwój wychowanków, przygotowanie ich do samodzielnego życia w rodzinie i społeczeństwie, radzenia sobie $w$ różnych sytuacjach dnia codziennego, współdziałania w zespole i ponoszenia odpowiedzialności za własne czyny, naśladowania pozytywnych wzorców, właściwej organizacji czasu wolnego poprzez rozwijanie i rozbudzanie zainteresowań. Różnorodność organizowanych zajęć daje wychowankom możliwość wyboru tych najbardziej odpowiednich dla siebie, zgodnie z własnymi predyspozycjami, zainteresowaniami i uzdolnieniami.

Zajęcia rewalidacyjno-wychowawcze zespołowe prowadzone są dla dzieci i młodzieży z głęboką niepełnosprawnością intelektualną w przedziale wiekowym 3-25 lat. Zajęcia te mają charakter zindywidualizowany. Praca z dziećmi oparta jest na indywidualnym programie zajęć (IPZ). 
Grupa zajęciowa składa się z 2-4 uczestników. Pracę w grupach wspierają inni specjaliści.

Wczesne Wspomaganie Rozwoju Dziecka (WWRD) to zajęcia organizowane dla dzieci, które uzyskały opinię o potrzebie wczesnego wspomagania ich rozwoju w poradnie psychologiczno-pedagogiczneją. Dziecko może w nich uczestniczyć od chwili wykrycia niepełnosprawności do momentu podjęcia nauki w szkole. Mają one na celu pobudzanie psychoruchowego i społecznego rozwoju dziecka. Zajęcia w ramach wczesnego wspomagania organizuje się w wymiarze od 4 do 8 godzin w miesiącu, w zależności od możliwości psychofizycznych i potrzeb dziecka.

SOSW w Stoku Lackim wyposażony jest w nowoczesne sale lekcyjne, pracownie gospodarstwa domowego, Salę Doświadczania Świata, salę integracji sensorycznej, gabinet komunikacji alternatywnej, pracownię „Małej poligrafii”, siłownię, oraz salę gimnastyczną.

Ośrodek posiada także bogatą infrastrukturę terenową, na którą składa się nowoczesny system dróg wewnętrznych i parkingów, boisko o nawierzchni sztucznej, stale rozbudowywany plac zabaw z huśtawką dla osób na wózkach i z trampolinami, a także ogród terapeutyczny ze ścieżką sensoryczną. Ośrodek został wyposażony w system solarny zapewniający najnowocześniejszy sposób pozyskiwania ekologicznie czystej energii do ogrzewania wody. Na wyposażeniu ośrodka są dwa pojazdy. Autobus 16-osobowy dostosowany do potrzeb osób niepełnosprawnych ze specjalnymi mocowaniami dla wózków oraz bus 9-osobowy przystosowany do potrzeb osób niepełnosprawnych ruchowo z najazdem dla 2 wózków.

Proces edukacyjno-terapeutyczny wzbogacony jest szeroką ofertą uroczystości szkolnych, wystaw, festiwali, konkursów oraz wycieczek, m.in. do miejsc użyteczności publicznej i instytucji kultury. 